\title{
Strategi Coping Stress Belajar Daring pada Siswa SMA Kota Padang
}

\author{
Ananda Zulaikha \\ Universitas Negeri Padang \\ e-mail: anandazulaikha14@gmail.com
}

\begin{abstract}
Abstrak
Penelitian ini bertujuan untuk mengetahui jenis-jenis strategi coping yang dilakukan oleh siswa SMA kota padang saat pembelajaran daring. Penelitian ini menggunakan jenis penelitian deksriptif kuantitatif survey, survey dilakukan dengan cara menyebarkan kuesioner melalui google form kepada siswa SMA Kota Padang pembelajaran daring. Subjek penelitian ini sebanyak 83 orang Siwa SMA Kota Padang. Teknik analisis data yang digunakan adalah persentase coping stress. Hasil penelitian menunjukan bahwa $77 \%$ Siswa SMA Kota Padang menggunakan jenis strategi coping dengan bentuk problem focused coping.
\end{abstract}

Kata kunci : Strategi Coping, Stress, Siswa SMA

\begin{abstract}
This study aims to find out the types of coping stress strategies carried out by padang city high school students during learning. The research uses a type of descriptive quantitative research survey method, the survey was conducted by distributing questionnaires through google form related to coping stress strategies to students of Padang City High School during learning. The subject of this study was 83 siwa people of Padang High School. Data analysis techniques in the research is the percentage of coping stress. The results showed that $77 \%$ of padang high school students use a type of coping strategy with the form of problem focused coping.
\end{abstract}

\section{Keywords: Coping Strategies, Stress, High School Students}

\section{PENDAHULUAN}

Covid-19 awal dikabarkan terdeteksi di Kota Wuhan, Provinsi Hubei, China, penyebarannya sangat cepat yang dapat meyebabkan kematian serta infeksi pernapasan pada paru-paru (Kompas). Virus ini sudah menyebar dihampir seluruh belahan dunia dengan tingkat kematian yang tinggi termasuk di Indonesia. Pada tanggal 2 Maret 2020 Covid-19 terdeteksi tesebar di Indonesia (Kompas).

Menurut data yang di rilis oleh Satgas Covid-19, jumlah kasus masyarkat yang terkonfirmasi positif hingga Desember 2020 sebanyak 743.198 orang dengan tingkat kesembuhan 611.097 dan jumlah yang meninggal dunia sebanyak 22.138 orang. Di Kota Padang kasus terkonfirmasi Covid-19 sebanyak 12.252 orang, dengan tingkat kesembuhan sebanyak 11.581 orang dan meninggal dunia sebanyak 251 orang (Website Corona Sumbar). Angka tersebut terus berubah mengikuti perkembangan Covid-19 yang di pantau oleh Satgas Covid-19.

Covid-19 membawa dampak dan perubahan yang besar di berbagai negara, tidak pada sektor kesehatan saja tetapi juga mempengaruhi pendidikan, perekonomian dan interaksi sosial. Pemerintah berupaya mengeluarkan kebijakan dalam menanggulangi pandemi, mulai dari melakukan social distancing, work from home (WHF) hingga pembatasan sosial berskala besar (PSBB) (Aufar, 2020). Pemerintah mengubah sistem pembelajaran, dengan mengalihkan proses pembelajaran guna menghindari kerumunan demi memutuskan rantai penyebaran Covid-19 (Mustofa dkk, 2019). Maka pemerintah melakukan perubahan sistem pembelajaran tatap muka dengan cara melakukan peroses pembelajaran daring (Dwi, 2020). Pembelajaran daring merupakan proses pembelajaran yang berbasis internet, dan 
semua aktifitas pembelajaran dilakukan secara daring/jarak jauh, misalnya: diskusi dengan guru, presentasi dan mengakses materi pelajaran melalui internet (Sadikin \& Hamidah, 2020). Keberhasilan penerapan sistem pembelajaran daring dipengaruhi oleh kesiapan sekolah, guru dan para pendamping siswa (Rusdiana \& Nugroho, 2020).

Namun, dalam pelaksanaan pembelajaran daring menimbulkan beragam masalah. Beberapa siswa mengeluhkan proses pembelajaran daring terkendala oleh kuota internet cepat habis sehigga menjadi permasalahan bagi siswa yang kurang mampu (Mahmudah, 2020). Selain itu siswa juga mengeluhkan kurang memahami materi pelajaran dan tugas yang diberi cukup banyak, sehingga siswa mengaku merasa kewalahan, jenuh, cemas dan merasa stress (Mahmudah, 2020). Sehingga, siswa merasa kebingungan dalam menyelesaikan tugas pada setiap mata pelajaran dalam waktu yang singkat.

Oleh sebab itu, tidak sedikit siswa merasa stress karena sistem pembelajaran daring. Penelitian yang dilakukan oleh Rinawati (2020) memaparkan bahwa pembelajran daring menyebabkan siswa mengalami kejenuhan dengan presentase $45 \%$ siswa hadapi tingkatan kejenuhan yang rendah serta 55\% siswa megalami tingkatan kejenuhan sedang. Sedangkan penelitian yang dilakukan oleh kartika (2020) megatakan bahwa selama pembelajaran daring siswa SMA merasakan kecemasan yang disebabkan oleh 4 faktor, 1) faktor internal dengan tingkat kecemasan $74,53 \%$ termasuk kategori sedang, 2) faktor keluarga dengan tingkat kecemasan $52,17 \%$ termasuk kategori sedang, 3) faktor sosial dengan tingkat kecemasan $52,80 \%$ dalam kategori rendah, dan 4) faktor kelembagaan dalam tingkat kecemasan $85,09 \%$ termasuk kategori sedang. Berdasarkan penelitian Taufik dkk (2013) menemukan hasil bahwa $71,8 \%$ Siswa SMA di Kota Padang mengalami tingkat stress sedang, serta13,2\% siswa SMA Kota di Padang mengalami tingkat stress tinggi dan 15\% siswa lainnya dengan tingkat stress rendah.

Stress merupakan reaksi individu terhadap bahaya, tantangan serta perubahan perstiwa hidup yang yang dialami oleh individu (Goal, 2016). Hal serupa juga dijelaskan oleh Hidayanti (2013) stress merupakan kondisi dan keadaan yang dapat membuat individu merasa tegang dalam menghadapi situsai yang penuh tekanan. Sehingga stres dapat berdampak pada diri individu baik secara fisik, psikologis, intelektual, sosial dan spiritual (Andriyani, 2019).

Menurut penelitian wahyuni (2017) respon stress dapat berupa proktasinasi, penarikan diri, gangguan tidur dan pola makan yang tidak teratur. Dilihat dari segi fisiologis, respon stress bisa berupa hipertensi, demam, keringat dingin, jantung berdebar, sakit perut (Sukadiyanto, 2010). Sedangkan secara psikologis, stress dapat diekspresikan sebagai bentuk kekecewaan, depresi, kebingungan, ketakutan, kejenuhan, dan kecemasan (Barseli, 2018). Bentuk respon tersebut dapat dipengaruhi seberapa besarnya tekanan stres yang diterima oleh seseorang dan seberapa siap seseorang menghadapi suatu masalah. Hasil penelitian terkait penyebab stress selama pandemi Covid-19 menunjukan 57,8\% merasa bosan karena dirumah saja, 40\% merasa kesepian karena tidak bertemu dengan teman, $55,8 \%$ merasa stress karena pembelajaran daring (Livana, Mubin \& Basthomi, 2020).

Lazarus dan Folkman (1984) mengatakan bahwa banyaknya kondisi atau problematika yang menyebabkan individu stress, maka individu akan berusaha mencari cara untuk mengatasi kondisi penyebab stress, stress dapat diatasi dengan strategi coping. Individu yang berada dalam situasi penuh tekanan serta kemampuan strategi coping yang rendah maka akan cendrung mengalami stress yang berat, bila individu berada pada tekanan yang rendah serta kemampuan strategi coping yang dimiliki tinggi maka akan cendrung mengalami stress yang sedang atau rendah (Larkin, 2005). Individu yang memiliki sumberdaya atau kemampuan coping maka dapat mempengaruhi kemampuan Strategi Coping dalam mengatasi permasalahan (Maryam, 2017).

Kata koping mempunyai makna yaitu penanggulangan atau mengatasi (Siswanto, 2007). Sehingga coping dapat diartikan sebagai cara individu dalam menyelesaikan masalah yang menyebabkan stress (Hidayanti, 2013). Hal senada juga dijelaskan oleh Indirawati (2006) coping merupakan strategi individu dalam menyikapi respon dan perilakunya dalam memecahkan masalah, sehingga individu mampu beradaptasi dengan kondisi yang 
meyebabkan stress. Sedangkan Lazarus \& Folkman (1984) berpendapat bahwa coping merupakan proses dan tindakan yang diambil oleh individu untuk mengelola tuntutan dan kemampuan diri dalam menghadapi tekanan. Jadi, strategi coping stress yaitu cara individu mengatasi, mengurangi, serta menyikapi segala bentuk stress yang dialaminya.

Lazarus \& Folkman (1984) mengelompokan strategi coping menjadi dua macam yaitu: a) Emotional focused coping, merupakan upaya yang dilakukan individu dalam mengontrol respon stress yang berhubungan dengan emosi, yang terdiri dari: 1) Positive reappraisal (Penilaian yang positif), yaitu pengembangan diri yang positif dan berkmana, 2) Accepting responsibility (Penanggung jawaban) yaitu menumbuhkan akan kesadaran diri tentang peran diri sendiri dalam penyelesaian masalah 3) Self controlling (Pengendalian diri) merupakan kemampuan individu dalam meregulasikan perasaan dan tindakan 4) Distancing (menjaga batasan) merupakan tindakan yang dilakukan agar tidak berdiam diri dalaam suatu permasalahan 5) Escape avoidance (menarik diri) merupakan tindakan lari dari masalah. Strategi coping stres dapat melibatkan strategi perilaku, maupun strategi psikologis pada diri individu. b) Problem focused coping, merupakan bentuk upaya yang dilakukan seseorang dalam mencari cara-cara baru dalam mengatasi masalah yang menyebabkan stress, yang terdiri dari : 1) Planful problem solving, merupakan tindakan yang dilakukan untuk mengubah situas penyelesaian masalah, 2) Confrontative coping, ialah perlakuan yang dilakukan untuk mengatasi masalah secara konkrit, 3) Seeking social support, merupakan tindakan mencari dukungan emosional, informasi maupun bantuan dari orang lain (Purna, 2020).

Belt (Andriyani, 2019) menjelaskan ada dua metode coping, yaitu: 1) Metode coping jangka pendek, yaitu mengurangi stress dalam waktu sementara dengan cara melakukan hal yang disuka agar bisa melupakan permasalahan yang sedang dihadapi, seperti tidur dan menangis, 2) Metode coping jangka panjang, yaitu mencari solusi yang efektif untuk mengatasi permasalahan yang dialami, seperti berbagi cerita ke orang terdekat, mencari solusi dan mengambil hikmah atas masalah yang telah terjadi.

Oleh sebab itu siswa yang mengalami stress karena pembelajaran daring diharapkan dapat melakukan strategi coping guna mengatasi, mengurangi dan menyikapi penyebab stress yang dihadapinya.

\section{METODE}

Penelitan ini menggunakan metode kuantitatif dekriptif yang bertujuan untuk menjelaskan dan menggambarkan suatu fenomena (Bungin, 2005). Riset ini bertujuan buat mengenali tipe strategi coping yang digunakan oleh siswa SMA saat proses pembelajaran daring dimasa pandemi. Populasi pada penelitian ini yaitu Siswa SMA Kota Padang dari kelas 10 hingga kelas 12 . Metode pengambilan sampel memakai puposive sampling, ialah metode pengambilan sampel yang memakai persyaratan atau kriteria tertentu (Sugiyono, 2017). Adapun kriteria atau persyaratannya yaitu Siswa SMA yang berskolah di Kota Padang. Sampel yang dipakai pada penelitian sebanyak 83 siswa. Pengambilan data dilakukan menggunakan kuesioner yang disusun melalui google form. Kuesioner merupakan cara pengumpulan data yang fleksibel dan relatif mudah digunakan dengan bentuk data yang faktual yang berupa pernyataan atau pertanyaan tertulis (Kumar, 1999). Data yang didapatkan lalu dianalisis menggunakan analisis statistik dengan aplikasi SPSS.16 dan Microsoft excell 2007.

\section{HASIL DAN PEMBAHASAN}

Penelitian ini dilakukan kepada 83 Siswa SMA Kota Padang dengan karakteristik sebagai berikut:

Tabel 1.

Jenis kelamin

\begin{tabular}{ccc}
\hline Jenis Kelamin & Jumlah sampel & Persentase \\
\hline Laki Laki & 25 & $30 \%$ \\
Perempuan & 58 & $70 \%$ \\
\hline Total & 83 & $100 \%$ \\
\hline
\end{tabular}


Dari tabel diatas (tabel 1) memaparkan jumlah responden yang terlibat dalam riset ini terbagi atas 25 orang laki-laki $(30 \%)$ dan 68 orang perempuan (70\%).

\section{Tabel 2.}

Usia

\begin{tabular}{ccc}
\hline Umur & Jumlah sampel & Persentase \\
\hline 15 Tahun & 13 & $16 \%$ \\
16 Tahun & 38 & $46 \%$ \\
17Tahun & 27 & $32 \%$ \\
18 Tahun & 5 & $6 \%$ \\
\hline Total & 83 & $100 \%$ \\
\hline
\end{tabular}

Tabel tersebut (Tabel 2) menjelaskan rentangan usia responden yang mana repsonden berusia 15 tahun sebannyak 13 orang (16\%), 16 tahun berjumlah 38 orang (46\%), 17 tahun berjumlah 27 orang (32\%) dan berusia 18 tahun sebanyak 5 orang $(6 \%)$

Tabel 3.

Bentuk strategi coping stress

\begin{tabular}{ccc}
\hline Strategi Coping Stress & Jumlah (org) & Persentase (\%) \\
\hline Problem Focused Coping (PFC) & 64 & $77 \%$ \\
Emotional Focused Coping (EFC) & 11 & $13 \%$ \\
Menggunakan Problem & & $10 \%$ \\
Focused Coping (PFC) & 8 & \\
maupun & & $100 \%$ \\
\hline Emotional Focused Coping (EFC) & 84 &
\end{tabular}

Tabel 3 menunjukkan bahwa sebanyak $77 \%$ responden (64 total) cenderung memakai strategi problem focused coping (PFC), sedangkan hanya 13\% responden (total 11) cenderung memakai strategi emotional focused coping (EFC). Serta responden yang memakai antara strategi problem focused coping dan emotional focused coping sebanyak $10 \%$ (total 8 ).

\section{Diagram lingkaran 1}

Diagram ini menunjukkan strategi koping yang digunakan oleh siswa SMA Kota Padang.

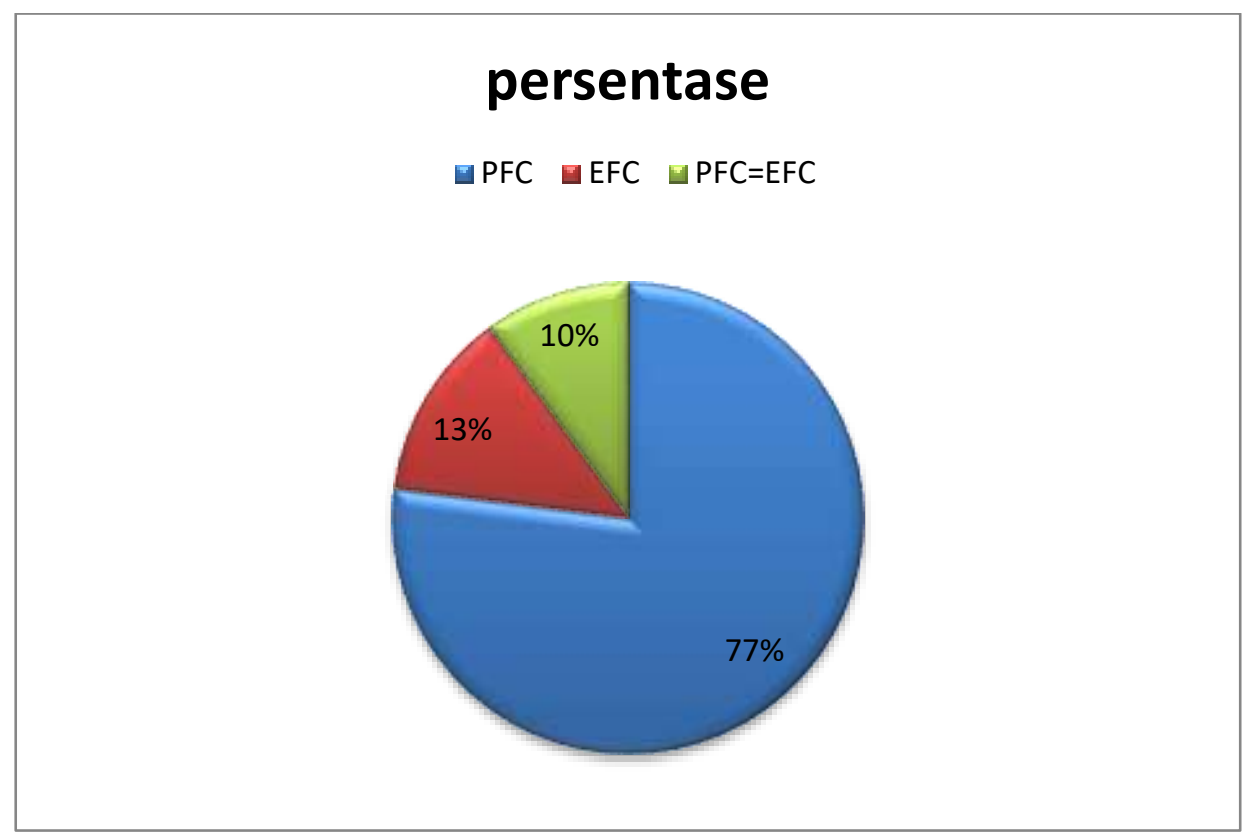


Tabel 4.

\begin{tabular}{|c|c|c|c|c|}
\hline $\begin{array}{l}\text { Jenis } \\
\text { Stress }\end{array}$ & Coping Sub Coping Stress & $\begin{array}{l}\text { Perolehan } \\
\text { Skor }\end{array}$ & $\begin{array}{l}\text { Skor Total } \\
\text { Maksimal }\end{array}$ & Persentase \\
\hline \multirow{4}{*}{$\begin{array}{l}\text { Problem } \\
\text { Focused } \\
\text { Coping }\end{array}$} & $\begin{array}{l}\text { Seeking } \\
\text { informasional support }\end{array}$ & 1699 & 1.992 & $85.3 \%$ \\
\hline & Plantful problem solving & 1624 & 1.992 & $81.52 \%$ \\
\hline & Confortative coping & 823 & 996 & $82.63 \%$ \\
\hline & Distancing & 575 & 664 & $85.59 \%$ \\
\hline \multirow{4}{*}{$\begin{array}{l}\text { Emotional } \\
\text { Focused } \\
\text { Coping }\end{array}$} & Escape avoidance & 528 & 664 & $79.51 \%$ \\
\hline & Accepting responsibility & 744 & 996 & $74.69 \%$ \\
\hline & Positive reappraisal & 861 & 996 & $86.44 \%$ \\
\hline & Seeking sosial & 498 & 664 & $75 \%$ \\
\hline
\end{tabular}

Tabel di atas (Tabel 3) menjelaskan bentuk strategi koping berdasarkan sub-respons. Persentase setiap respons dihitung dengan membagi nilai total respons dengan total skor respons maksimum. Dengan demikian dapat dijelaskan bahwa sub respon yang sering digunakan oleh responden penelitian ini adalah sub respon positif re-evaluasi dari emosional focus coping (EFC) dengan proporsinya sebesar $86,44 \%$. Metode coping kedua yang digunakan oleh responden penelitian adalah problem focused coping (PFC) yang mencapai $85,63 \%$, sedangkan metode respon ketiga yang digunakan adalah mencari informasi tentang solusi dari masalah tersebut. Rasionya $85,3 \%$. Strategi koping yang digunakan oleh responden dapat dipengaruhi oleh budaya, lingkungan, pengalaman dan pengetahuan (Gunawan, 2018).

\section{Pembahasan}

Berdasarkan hasil penelitian yang dilakukan, sebanyak $77 \%$ responden (64 total) cenderung menggunakan strategi koping stres dalam metode pemecahan masalah (PFC), sedangkan hanya $13 \%$ responden (total 11 ) cenderung menggunakan solusi emosional (EFC). 10\% responden yang tersisa menggunakan strategi yang seimbang antara respons yang berpusat pada permasalahan serta respons yang berpusat pada emosi. Sehingga hasil tersebut dapat menjelaskan bahwa sebagian besar siswa SMA di Kota Padang menggunakan jenis strategi coping dengan bentuk problem focused coping, yang merupakan upaya individu untuk mencari cara-cara baru dalam mengatasi masalah yang menyebabkan stress (Adyafnita, 2019).

Individu yang menghadapi stressor (sumber stress) akan berusaha melakukan perilaku coping. Sehingga, dalam kehidupan sehari-hari siswa saat menghadapi situasi penuh tekanan, seperti situasi pembelajaran daring. Dimana siswa mencoba mengatasi masalah dengan mencari solusi dari permasalahan ketika pembelajaran daring. Namun strategi coping yang digunakan oleh responden dapat dipengaruhi oleh budaya, lingkungan, pengalaman dan pengetahuan (Gunawan, 2018). Maka dari itu, Startegi coping stress pada siswa sama selama pembelajaran daring sangat penting dilakukan, karena strategi coping yang dilakukan oleh individu berpengaruh positif terhadap kemampuan mengatasi stress akademik (Sumantyo, 2020)

Responden yang berpartisipasi pada riset ini lebih banyak wanita dari pada pria. Hingga, riset ini berbanding terbalik dengan riset yang dicoba oleh Patton (2006) yang berpendapat bahwa perempuan lebih banyak menggunakan jenis strategi coping dengan bentuk emotional focused coping dalam mengatasi stress. 


\section{SIMPULAN}

Berdasarkan penjelasan diatas dapat simpulkan bahwa siswa SMA Kota Padang lebih banyak menggunakan jenis strategi coping dengan bentuk problem focused coping (PFC). Dan hasil penelitian juga menunjukan bahwa jenis kelamin tidak mempengaruhi jenis strategi coping yang digunakan oleh siswa SMA Kota Padang. Dari pemaparan hasil penelitian yang telah dijelaskan, saran kepada peneliti berikutnya supaya bisa mempelajari lebih mendalam mengenai strategi coping stress dan apa saja aspek-aspek yang mempengaruhi strategi coping yang digunakan oleh Siswa SMA.

\section{DAFTAR PUSTAKA}

Adyafnita, R., \& Khairani, K. (2019). Coping Students in Working on Their Thesis. Jurnal Neo Konseling, 1(4). http://dx.doi.org/10.24036/00180ko s2019

Retrieved from

Andriyani, J. (2019). Strategi coping stres dalam mengatasi problema At Taujih, 2(2), 37-55. http://dx.doi.org/10.22373/taujih.v2 2.6527

Aufar, A. F., \& Raharjo, S. T. (2020). Kegiatan relaksasi sebagai coping stress di masa pandemi covid 19. Jurnal Kolaborasi Resolusi Konflik, 2(2), 157-163 https://doi.org/10.24198/jkrk.v2i2.2 126.g13931

Barseli, M., Ahmad, R., \& Ifdil, I. (2018). Hubungan stres akademik siswa dengan hasil belajar. Jurnal EDUCATIO: Jurnal Pendidikan Indonesia, 4(1), 40-47. http://dx.doi.org/10.29210/1201821 6

Bungin, B. (2005). Metodologi Penelitian Kuantitatif Komunikasi. Ekonomi, dan Kebijakan Publik serta IImu IImu Sosial Lainnya. Edisi Pertama, Cetakan Pertama, Prenada Media, Jakarta.

Kompas.id. (2020, April 18). Rangkaian peristiwa pertama Covid-19. Di akses pada tanggal 1 januari 2021 dari https://bebas.kompas.id/baca/riset/2 20/04/18/rangkaian-peristiwa pertama-covid-19/

Dewi, W. A. F. (2020). Dampak Covid-19 terhadap implementasi pembelajaran daring di Sekolah Dasar. Edukatif: Jurnal IImu Pendidikan, 2(1), 55-61. https://doi.org/10.31004/edukatif.v2 1.89.

Gaol, N. T. L. (2016). Gaol, N. T. L. (2016). Teori stres: stimulus, respons, dan transaksional. Buletin psikologi, 24(1), 1-11. Retrieved from https://jurnal.ugm.ac.id/buletinpsikoogi/article/view/11224.

Hidayanti, E. (2013). Strategi coping stress perempuan dengan hiv/aids. Sawwa: Jurnal StudiGender, 9(1), 89-106. Retrieved from Https://journal.walisongo.ac.id/index hp/sawwa/article/viewFile/667/605

Lazarus, R. S., \& Folkman, S. (1984). Stress, appraisal, and

coping. Springer publishing company.http://libgen.gs/ads.php? d5=7965cdc5d7f7dd5143146b6b53 6b5b5

Mahmudah, S. R. (2020). Pengaruh Pembelajaran Daring terhadap Psikologis Siswa Terdampak Social Distancing Akibat Covid 19. Al Mau'izhoh, 2(2).

Retrieved fromhttp://jurnal.unma.ac.id/index.php/ m/article/view/2293

Sadikin, A., \& Hamidah, A. (2020). Pembelajaran daring di tengah wabah Covid-19. Jurnal Ilmiah Pendidikan Biologi, 6(2), 214-224. https://doi.org/10.22437/bio.v6i2.9 59

Satgas penanganan covid-19. (2020). Dat penyebaran. Retrieved from https://covid19.go.id/

Sugiyono.(2017). Metode penelitian kuantitatif, kulitatif, dan kombinasi. Bandung: Alfabeta.

Sumantyo, F. D. S. (2020). Pendidikan tinggi di masa dan pasca Covid-19. Jurnal Kajian IImiah, 1, 81-92. https://doi.org/10.31599/jki.v1i1.266

Sukadiyanto, S. (2010). Stress dan cara menguranginya. Jurnal Pendidikan, 1(1). Retrieved from https://scholar.google.com/scholar? l=id\&as_sdt=0\%2C5\&q=stress+da +cara+menguranginya\&oq=stress + an+cara+ 
Taufik, T., Ifdil, I., \& Ardi, Z. (2013). Kondisi stres akademik siswa sma negeri di kota padang. Jurnal Konseling dan Pendidikan, 1(2), 143-150. https://doi.org/10.29210/12200

Website Corona Sumbar. (2020). Data Pantauan COVID-19 Provinsi Sumatera Barat. Retrieved from https://corona.sumbarprov.go.id 